\title{
Masculinities and mergers: losing ground through
}

\section{territoriality}

Introduction

This paper emerges from a study of a merger process between two South African education institutions ${ }^{1}$. One was a large ${ }^{2}$, well established university, which I refer to as the University. The other was a small, relatively new college, which I refer to as the College. What was meant to be a merger process quickly turned into the incorporation $^{3}$ of the College into the University. In this paper I examine the effects of masculine posturing on this process.

I begin with a description of the data collection process, a discussion of the key players and appropriate contextual detail to facilitate understanding of the incorporation process. This is followed by a review of the literature on masculinities. Two points emerge through this review. The first is that, despite the obvious linguistic connections, masculinities and masculine behaviour is not the preserve of men. The second is that in the South African context, and arguably in others, institutional behaviour has often been dominantly masculine. I then draw on the data and demonstrate the links between masculinities and discourse of power and territoriality. A single point emerges: that the presence of masculine voices and posturing in the

\footnotetext{
${ }^{1}$ V Soobrayan 2003. Transformation or travesty? A study of the micropolitics of educational change in the case of the incorporation of a college of education into a university. Unpublished doctoral thesis. University of Pretoria. Note that since the completion of this thesis I have changed my surname to Pillay.

${ }^{2}$ This in defined in terms of student and staff numbers.

${ }^{3}$ I do not want to delve into an examination of the term incorporation here and to distinguish it from other merger forms. Suffice to say that, from the outset, this term was used by the players in this particular case. In practice it meant that the College was absorbed into the University, leaving no trace of the College. In merger terms this may be likened to an acquisition. For details of this case study and other comparative studies that occurred at the same time, see J D Jansen (ed) 2002. Mergers in higher education: lessons learned in transitional contexts. Pretoria. University of South Africa.
} 
merger process, and probably in other education change processes, gain volume and dominance at the expense of other potentially beneficial practices and voices.

\section{Contextual background}

- Data collection

The data that I use in this paper is part of the data collected for my doctoral thesis. A total of 81 interviews were conducted. ${ }^{4}$ I began the data collection in July 2001 and completed this at the end of 2002. Thirty six academic and five senior management staff at the college were interviewed. These included the Rector, Senior Vice Rector, the Academic Vice Rector, the Vice Rector for Labour Relations and the Registrar. Six administrative staff were interviewed individually and a further fifteen in focus group discussions. Seventeen academics from the university were interviewed. The senior management interviewed were the Acting Vice Chancellor of the University, the Deputy Dean of the Faculty of Education and a senior faculty member who was involved in the merger process. Three administrative staff members from the University played a key role in providing data. Individuals from key government and related institutions included the following:

- The Deputy Director-General of the National Department of Education (DoE)

- The Chief of Higher Education Planning at the DoE.

- A senior official seconded to the DoE to guide the merger process

\footnotetext{
${ }^{4}$ Where possible pseudonyms are used when quoting respondents. Senior officials are indicated by the position they occupied. In some instances dates of interviews are not given to protect the identity of some respondents.
} 
- The Deputy Director-General of the provincial Gauteng Department of Education (GDE).

- The Chief Director of Education and Training in the GDE.

- Two other key officials from the GDE

- The independent facilitator from the Joint Education Trust (JET).

- The head of the University Council.

- An individual from the South African Institute for Distance Education (SAIDE) 5 .

Although the research focused on stakeholder experiences of government policy, I repeatedly encountered comments that drew my attention to the possibilities of masculinities at play in the process. It is these comments I draw I on in this paper.

- The key players

There are four key players I consistently refer to in this paper: the University, the College, the national department of education (DoE) and the provincial Gauteng Department of Education (GDE). The College was administered by and was accountable to, the GDE. The University, while an autonomous institution, had a level of accountability to the DoE.

The University is one of the oldest in South Africa, having is origins in the late 1800s. At the time of the study referred to above (2002) the education faculty was headed by a Dean, assisted by two Deputy Deans with 86 academic and nine administrative staff. In the main, the incorporation process was negotiated and

\footnotetext{
${ }^{5}$ She was responsible for incorporating the curriculum of the College into the University.
} 
implemented through this faculty. The rest of the University management was peripherally involved in the process. In the three years preceding this incorporation the faculty of education at the University had experienced a significant decline in student enrolments. In the course of my interviews, a repeated concern among academics at the University was the possibility of job losses due to decreased student enrolments ${ }^{6}$.

The College was formed as a result of a merger between a historically white college and a historically black college. As the new merged institution, it was barely five years old at the time of the incorporation. At this point the senior management of the College consisted of the Rector, a senior Vice-rector and five Vice Rectors.

Both institutions are situated in a politically conservative city which was and still is dominated by government officials. Historically, there have been consistent informal networks between the two institutions, one example being a mentoring arrangement between the two institutions.

The GDE is a coalescence of the various ethnically based provincial education departments of the apartheid era in South Africa. As a consequence, after the first democratic elections in 1994 many black senior officials in the GDE acquired positions of authority over white educators in the province for the first time. This situation prevailed vis-à-vis the College and the GDE. Data from the larger study revealed that a tense and somewhat acrimonious relationship existed between the

\footnotetext{
${ }^{6}$ See JD Jansen (ed) 2002. mergers in higher education: lessons learned in transitional contexts. Pretoria. University of South Africa Press and Soobrayan V 2003. Transformation or travesty? A study of the micropolitics of educational change in the case of the incorporation of a college of education into a university. Unpublished doctoral thesis.
} 
GDE and the College. One accusation of individuals in the GDE was that the College was spending money lavishly and was functioning as a privileged white institution. Many respondents at the College believed that there was a tussle for power and authority between the GDE and the College and this played itself out in the incorporation process.

The national Department of Education was the authority that developed the plan, in 1997, for the rationalisation and restructuring of the higher education system nationally. Simultaneously, the process was intended to move colleges of education into the higher education sector and therefore from the competence of a provincial authority to the competence of the DoE. The implementation of the plan rested mainly on the provincial education departments, in this case the GDE. Given that the GDE and the DoE were relatively new government structures, lines of authority were not unambiguously drawn at the time of the incorporation process. There was some feeling within the GDE that the DoE should have played a stronger role in the incorporation process, becuase universities were independent institutions and the GDE had no authority over them. However, it is arguable that the DoE had negligible, if any, authority over universities as well. ${ }^{7}$

In summary, there appeared to be tangible tensions between the key players such tension emanating largely from contested relations of power and authority. It is not surprising, therefore, that these contestations fuelled the incorporation process and took on multiple manifestations throughout. One of these manifestations was in the masculinities that pervaded the process.

\footnotetext{
${ }^{7}$ See doctoral study referred to in Footnote 1.
} 
- Distinguishing features of the College/University incorporation

An incorporation with no leadership is probably unimaginable to students of mergers in higher education. Yet this is precisely what happened in the case of the incorporation of the College into the University. Its defining uniqueness was that no team or individual led the process of this incorporation. Instead, the process may be described as a free for all in which the stakeholders sought to serve their own ends as far as was possible. A facilitation agency was appointed for a six-month period but the project manager admitted to giving up on the task when it appeared to her that the parties involved in the incorporation were determined not to cooperate with each other. The power struggles that emerged over the more than two-year period of this incorporation were intense and deeply politicised. It became increasingly clear that none of the parties was willing to give up without a fight.

Another distinguishing feature of this incorporation is that it took place with no written agreements binding the process. At the time of writing more than three years after the completion of the incorporation, no government official that I spoke with at the DoE or the GDE could confirm that an agreement had been finalised.

A third distinguishing, if not unique, feature of this incorporation was that the incorporated institution, the College, reputedly had a significant number of students ${ }^{8}$, yet it did not enjoy any benefit of power or recognition as a result of such large student numbers. On the other hand, the University exercised the benefits of the traditional power and status advantage that a university has over an education

\footnotetext{
${ }^{8}$ See J D Jansen (ed) 2002. Mergers in higher education: lessons learned in transitional contexts, Pretoria, University of South Africa.
} 
college. The Rector of the College chose not to lead the college through the incorporation. Instead, he actively opposed the incorporation thereby leaving the college with no authority figure to take it through a turbulent period. I shall show here that the turbulence was part of the masculinities that was played out in this process.

\section{Understanding masculinities}

An initial problem I confronted was whether to equate masculine behavior with that of males. At a practical level this would not have been possible. The four significant players in the process the DoE, GDE, the University and the College all had women in notable leadership and authority positions vis-à-vis the incorporation process. The Deputy-Director General (the head) of the Higher Education Branch at the DoE was a woman. The second in command of the process at the GDE was a woman, the Senior Vice Rector at the College was a woman and so too the Dean of the Faculty of Education at the University. In addition, the independent facilitator for the process was a woman. To all intents and purposes, there was theoretically, despite its numerical insignificance, a notable senior female presence in the process. However, a closer look at the process suggested that the tangible and visible presence of women in the process was debatable, despite their occupying positions of authority in their respective institutions. The Deputy Director General at the DoE, stayed largely out of the process. The Rector of the College described a meeting that he had with senior members of the DoE and he noted the Deputy Director General did not say anything but simply "sat there". According to another respondent, she was part of the team of government officials who first approached the university with the idea of incorporating the college, but I found no evidence of any other direct 
involvement on her part. Indeed in my interview with her she indicated that much of the work of the merger was left to her second in command, a male.

The woman facilitator abandoned her task a short while into the incorporation process, saying that she was unable to do her job effectively as she was being asked to do things outside her brief. Her actions left the entire process without an independent facilitator, rendering it vulnerable to the machinations of individuals from the institutions involved. The Dean of the Faculty of Education at the University played no visible role in the incorporation. She did not meet with the college staff as she had indicated she would. The responsibility for the entire process was left in the hands of a male Deputy Dean. Indeed, all the senior management closely involved with the process at the University were male. On the other hand, the authority of the woman official at the GDE was perceptible throughout the process. Individuals within and outside the GDE commented on her wielding of institutional power and authority. At the College the Senior Vice Rector, a woman, was instrumental in taking the college through the process. Unfortunately she constantly came into conflict with the male Rector who strongly opposed the incorporation.

What this biological sauntering through these institutions suggested to me was that the sense of masculine posturing I perceived had no unambiguous connection with whether males or females were in positions of authority. The fact that there was a very small number of women who held positions of authority in this process also did not seem to be too significant. It was the role they played or did not play; it was the stances taken by the institutions; and it was the message that each institution articulated, through its leadership, whether male or female, that was more instructive. 
In the sections that follows I use the current literature on masculinities to examine relevant data collected in the case study with the aim of explaining the perceived masculinities that permeated this particular incorporation process.

The linguistic intimacy between the terms "masculinity" and "male" presupposes a relational link between being male and the masculine. Robert Connell (1995) offers a useful summary of a variety of approaches to understandings of masculinities, some of which reduce this link to its simplest forms. Of importance are his comments on why essentialist and positivist views on masculinities are limited and not a useful of understanding them. The essentialist view suggests that there are core characteristics of men, which define the masculine. Positivists adopt a similar position, but perhaps from the other end of the lens, and say that what men are is what is masculine. Aside from the arbitrariness of selecting characteristics that define the masculine, the problem is that essentialist and positivist definitions make a fundamental and irrefutable link between being a biological male and being masculine. While I do not wish to go into the problems this approach is likely to have for queer theorists and the entire body of literature on the differences between biology and social gender construction, for me the relevant point here is that a social divide premised on such a biological construction carries with it the danger that the qualities attributed to masculinity, such as aggression, violence and control, are the irredeemable and inevitable fate of men. Such a dangerous position is currently being taken up by the mythopoeic men who argue for a return to the essential nature of men - that men need to be men (whatever that may be). (see Michael Schwalbe, 1996) 
While I acknowledge the linguistic and historical link between being male and masculinity, I suggest that it is the social construction of masculinity that is of significance. It is in social contexts that masculinities become manifest and it is the social context that often shapes particular masculinities at a given historical moment. There is sufficient agreement in the literature on masculinities (Brittan, 1989; Connell 1995, 2000b, 2002; Kerfoot \& Knights, 1999; Morrell, 2001) that there are numerous masculinities each constructed in particular social contexts, in particular historical moments and across race, class and ethnicity. Associated with this approach is the notion of fluidity. As Robert Morrell (2001, p.4) puts it, "masculinity can and does change - it is not a fixed essential which all men have." It follows then that any given context is likely to comprise various masculinities operating simultaneously, some more powerful and visible than others. Indeed, Connell (2000b, p.13) makes the point that "one of the key reasons why masculinities are not fixed is that they are not homogeneous, simple states of being. Close-focus research on masculinity commonly identifies contradictory desires and conduct."

That there are bikers who consider themselves to be masculine and are often socially constructed as masculine by virtue of what they do and there are academics who feel that to "cut-your-opponent-down-to-size" (Schmitt, 2001, p.412) is a form of masculinity, implies that conceptions of masculinity are eminently varied. In some circles rape may be considered a form of masculinity. In her detailed and disturbing study of gang rape and masculinity in the Cape Flats ${ }^{9}$ area, Benita Moolman (2004) makes the following observation. "Gang rape provides male gang members with the means to control and own bodies, particularly women's bodies. Women's bodies are

\footnotetext{
${ }^{9}$ An area in the western Cape of South Africa. The area is notorious for its gang violence.
} 
used as a form of cultural capital and thus control over their bodies is a key aspect of gang members' masculinity" (2004, p.113). If masculinity is not a trait, a core characteristic or genetic constitution that is biologically determined, and if it is socially constructed, then its link to gender assumes prominence over its link to biology. Connell (1995, p.71) makes the point that "no masculinity arises except in a system of gender relations." He goes on to say:

[r]ather than attempting to define masculinity as an object (a natural character type, a behavioral average, a norm), we need to focus on the processes and relationships through which men and women conduct gendered lives. "Masculinity"', to the extent the term can be briefly defined at all, is simultaneously a place in gender relations, the practices which men and women engage that place in gender, and the effects of these practices in bodily experience, personality and culture (1995, p.71).

However, I do not mean to argue that biology and social construction are distinct dualisms in the development of identity. On the contrary, biology and social construction are intimately linked. As Arthur Brittan (1989, p.21) argues:

Roles are added to biology to give us gender - and, once this happens, men, and women acquire their ... gender identities. In a nutshell, the socialization thesis asserts that human beings acquire gender as a result of the social definition and construction of male or female bodies.

Connell (1995, p.71) takes this point further when he says that "[g]ender is social practice that constantly refers to bodies and what bodies do, it is not social practice 
reduced to the body... Gender exists precisely to the extent that biology does not determine the social."

In taking up Connell's point, it follows that the historical construction of gender and, by extension, masculinity and femininity is neither accidental nor arbitrary. In referring to Holter's (1989) study of gender, masculinity and femininity, Connell (2000b, p.22) observes that "Holter is able to show that the association of men with wage labour and women with domesticity is neither biologically determined nor arbitrary." In effect, social constructions and representations of masculinity exist. It is these constructions and representations that I call upon in examining the masculinity[ies] of this merger scenario. In doing so, I do not reduce my analysis to the behavior of the men in this incorporation process. Instead, I take my cue from Deborah Kerfoot and David Knights (1999) who refer to masculine and feminine subjects who are not necessarily defined by biological constitution. According to Kerfoot (1999, p.186)

[t]he concept of the masculine subject recognizes that both men and women can be masculine, although masculinity, in whatever manifestation, can be conventionally conceived as elevated and privileged as a range of behaviors for many men. Masculinity exists merely as a way of being, most often but not exclusively for men, in which men express what it is "to be a man" at any one time and in whatever location.

Theoretically then, it is possible for both men and women to behave in masculine ways and it is also possible for men to not behave in ways deemed to be stereotypically masculine. My analysis of the College/University case will use this 
perspective of the masculine subject and will refer to some of the dominant discourses of masculinity.

Given the focus on institutions in this paper, I want to briefly examine some of the current literature on gendering and institutions.

\section{Masculinities and institutions}

Current literature on masculinities affirms the idea that institutions are gendered and, in the main, exhibit masculine behavior. According to Connell (1995,

... social science [has] come to recognize a third site of gender configuration, institutions such as the state, the workplace and the school. Many find it difficult to accept that institutions are substantively, not just metaphorically, gendered ... The state for instance is a masculine institution.

There is little doubt that major corporates across the world are run by men (perhaps the Oprah corporation may be an exception) and governments are overwhelmingly dominated by men (Sweden may be an exception). Given this phenomenon, it is not surprising that certain discourses of masculinity also dominate the economic and political sphere. One such discourse is that of power closely allied to that of control. The hierarchical structure of economic and political institutions means that such power is a means of significant economic and political control. The institutional setting is an expedient space for the nurturing and advancement of stereotypical masculinity as expressed in the discourses of power. Kerfoot (1999, p.186) argues that there is an intimate link between masculinity and the activities of 
management and that "... the organizational locale is but one site for the construction and reconstruction of masculinity amongst many ... ". Kerfoot (1999, p.189) goes on to say that a "masculine mode of engaging with the organizational world is one in which all encounters and events become potential arenas for instrumental control". The idea of power and control and the inability to relinquish these obtains in much of the literature on institutional masculinity (Clark, 1999; Kerfoot, 1999; Maile, 1999; Connell, 2002). In presenting its face to the external environment and internal milieu of the organisation, the organisation seeks to maintain a hand of authority and power and assert its ability to control both internal and external environments. In the context of the discourses of masculinity, such a face is a masculine one. This is not to say that institutions have a life of their own that is discrete from the lives of the men and women who people the organisations. The men and women who enter organisations do so as gendered beings, not as neutral individuals subjected solely to the discourse of the institution. The gendering of individuals and the gendering of institutions are not separate and unrelated processes. I suggest that there is a dialectical and iterative link between institutional gendering and individual gendering.

On the other hand, management discourses themselves have been strongly imbued with masculinist discourses. Maile (1999, p.145) says that management discourse has often played a crucial role in shaping "masculinized work cultures." Indeed it can be argued that ways of managing have often been interpreted as ways of being men and vice versa. Indeed Kerfoot and Knights (1993, p.659) make the point that "'techniques' of managing people and organizations, are both constitutive of and embedded in what we term a 'discourse of masculinism' ". Lynn Davies (1998, 
p.16) refers to the "management discourse by one version of masculinity" as part of the problem of why women teachers did not easily apply for management positions.

In the South African context, the system of patriarchy, in which the structural arrangements of society serve to undermine the status of women, was a strong feature of the apartheid era. Despite an enlightened constitution that seeks to address the empowerment of women and despite numerous transformation mechanisms being in place, I suggest that the state is still a patriarchal institution. At an obvious level, leadership and management of the state is still overwhelmingly male. Evidence gathered for a study of gender equity in the education system points to the deep rooted patriarchal attitudes of male managers and leaders. ${ }^{10}$ This does not mean that the changes of the last decade have been meaningless. Rather it means that it takes more than 10 years of democracy (which in itself is not a cure for patriarchy) and commitment to change such deeply entrenched political and social ways of being. My point here is that the DoE and the GDE, both representations of the state, have a history of patriarchy that they are unlikely to shed in the near future. More significantly, the masculinist ways of operating, which were so endemic to the apartheid era, are still very much a part of the ethos and the functioning of these institutions. Morrell (2000, p.109) argues that the "political trajectory to liberation that was followed in South Africa saw the transfer of power from a white, male, Afrikaansspeaking elite, to an African, male elite." This observation is instructive in the analysis of this case because it underlies the education restructuring process: white males

\footnotetext{
${ }^{10}$ I was recently part of a Ministerial Reference Group set up to assess the gender equity achievements of government with respect to education. One of the overwhelming trends to emerge from the data collected from senior women government officials whose task it was to promote gender equity within the various departments of education was the strong and at times provocative resistance they met from male managers and leaders. The report of this commission is not yet available to the public.
} 
were losing power and authority and in the process they were accountable to black seniors. What emerges is that the transformation agenda, as far as the colleges of education were concerned often saw the replacement of one masculinity with another. Morrell (2000, p.110) further states that while the "state is mindful of the importance of gender in the process of restructuring the country ... [t]here are no government programs that consciously deal with issues of masculinity." It is not the purpose of this paper to investigate the effects of racial signifiers on modes of masculinity. However, it is feasible to make the point here that masculinity and the exercise of power remained an important feature of this state-initiated restructuring process.

In describing the nature of education institutions, which do not wield significant economic power, Ann Brooks (2001, p.16) observes that in education institutions the "production and management of knowledge have traditionally been the terrain dominated by men." The literature describing the masculine control of intellectual development and knowledge production, especially with regard to the hegemony of rationalism within education institutional cultures, is significant (Brooks, 2001; Hearn, 2001; Schmitt, 2001). The two education institutions involved in this incorporation process occupy particular places in the discourses of power. In local academic circles and indeed within local government organisations, the education faculty at the University had a reputation of intellectual conservatism that rested on an appeal to rationalism, strong hierarchy and established procedures. Aside from the Dean, the Senior Management of the Faculty was overwhelmingly male, the majority of whom had been at the university since the apartheid era. The college concerned had no intellectual reputation to speak of. Aside from a handful of individuals its staff had no 
notable publishing record. Indeed, prior to this merger process colleges of education functioned mainly as professional training institutions rather than academic institutions. In general the political and intellectual conservatism of colleges in the South Africa is evidenced in some of the literature on South African higher education (Hofmeyr \& Hall, 1996; National Commission on Higher Education, 1996).

In summary, my contention is that the institutions involved in this incorporation process have been historically masculine in their outlook and image, but more importantly, they remain masculine. In the next section where I look at relevant data collected in the study of this incorporation, I will show that the masculine character of the institutions as manifest in the actions of senior role-players mediated the way in which the process unfolded. In order to do this I shall look at two aspects of masculinist discourses that I found to be dominant in the process. These were the discourses of power and control, and of territoriality. Craig Prichard's (1996) quote of Kerfoot and Whitehead's (1995) comments on new managerialism in further education is telling. Kerfoot and Whitehead (1996, p.231) say that the "discourse of new managerialism in FE [Further Education] is consonant with, and constitutive of, a form of masculinity that achieves validation through control and power over others." In identifying these two features (control and power, and territoriality) I also want to assert their interrelatedness while simultaneously recognising that there may well have been other masculinity discourses that permeated this process, but which I do not address here. 
Discourses of power, discourses of masculinity

The association of masculinity with power has been documented by management theorists (Morrison, 1987; Nicholson, 1996; Reay \& Ball, 2000) and by gender theorists alike (Brittan, 1989; Connell, 1995, 2002; Morrell, 2001;). It is similarly instructive that the term, "emasculate", means to render powerless. In the incorporation process, certain implicit discourses of power obtained. One was the position of academic and status superiority that the university had over the College. That the College was to become part of the university and that this was inevitable, reinforced this element of power. The conception and unfolding of the restructuring process within the DoE was another means of leaving the College in a state of disempowerment. According to the Chief Director: Higher Education Planning, (interviewed 17 January 2002) "none of the colleges in one sense had any role ... there were discussions between the universities and technikons concerned, and the ... Provincial Department and the MECs [Member of the Executive Council]. The colleges weren't given much choice about deciding who they would be with eventually." In effect, from the outset, the process rendered the college powerless while simultaneously according the university a significant leverage of power. What this meant was that the Rector of the College, who up until the incorporation wielded considerable authority in the institution, had been emasculated. One of the criticisms that individuals in the GDE raised against the Rector was that prior to the incorporation becoming a reality the Rector had set about expanding the college and had set up regional offices throughout the country. The GDE argued that he was forcing the hand of the provincial education department to subsidise what was in practice a national education college (Shani, 19 November 2001). In addition, the Rector appointed a large number of staff early in 1998, despite the advice to the 
contrary from the College Council, and in the view of one Council member, thereby making the college inefficient and expensive to run (interview with Council member, 20 May 2002). It was not surprising that the Rector did not accept what was in effect an emasculation of his powers. Instead he fought back. ${ }^{11}$ Despite his statements that the incorporation was educationally unsound (Memorandum to the Minister, November 2000), in my interview with him (4 July 2001) he repeatedly made the point that if he had been treated differently the process may have gone differently. ${ }^{12}$ It is possible that the Rector may have seen the University as firing the first shot by its failure to act in a manner that recognised the authority of the Rector. Kerfoot and Knights (1999, p.201) suggest that "masculinity requires the constant approbation and gaze of acceptance by others".

I think that the first thing that ... should have happened was that Professor Melck [at the time acting Vice chancellor at The university] should have invited either the senior management as a group, or the Rector and the Vice rector up for a cup of tea and a chat.... If we had been invited by Melck, I would have probably had a better disposition towards it.... But I would always have opposed it [Rector of the College].

Not only did the external players fail to accord him such a "gaze of acceptance" (Schmitt: 2001, p.412), but it is also arguable that the attitude that the Rector perceived from the other players was a way of "cutting-him-down-to-size" (Schmitt:

\footnotetext{
11 Other members of the College management became involved with individuals from the University in facilitating the incorporation. Of course, this was not a smooth process and many battles were fought along the way. Of the staff at the College, I limit my discussion to the behavior of the Rector since it was his actions, or lack thereof, that were volubly and visibly read by other players in the process. Some respondents argued that it was primarily the actions of the Rector that set such an aggressive tone for the incorporation. While I do not subscribe to this reading, for the purposes of this paper his actions are central.

${ }^{12}$ For the sake of maintaining the flow of the paper, interview dates are reflected only the first time a respondent is citied.
} 
2001, p.412), because, according to interviews of individuals in the GDE, historically he had not really acknowledged the authority of the GDE. One of the respondents at the GDE was particularly scathing. She said that the College

had created all lecturing positions that they didn't qualify for - video cameras and all fancy nice-to-haves. And they created this when we were struggling with regards to rationalisation and redeployment. ${ }^{13}$ And this had to come out of our budget these nice-to-haves. And they were servicing the whole country. And yet we had to pick up the tab ... For us [the College] was an extension of job creation for redundant boers ${ }^{14}$ as a technical college used to be. That's basically what our perception of [the College]was (Shani, official at the GDE, 19 November 2001).

Furthermore, members of the Rector's own staff displayed a negative attitude towards him. Indeed, there was a view among his staff that he had relinquished his duty as the leader of the college and that, as a man, he was somewhat autocratic. Although he perceived the other players to be somewhat intransigent and unconcerned, members of his staff had a similar opinion of him.

I saw that it's his personality. Unfortunately he is not a democratic leader you know. If he has his point of view he wants his point of view to be happening. ... a good leader is a democratic leader not an autocratic leader. (Julia, 17 July 2001).

\footnotetext{
13 As a consequence of a national rationalisation policy the GDE and other provincial departments had to redeploy a large number of staff from various colleges.

${ }^{14}$ An emotionally laden term, often used with the intention of being derogatory. It refers to white Afrikaners. Literally the term means "farmers".
} 
[The Rector] was the main head. And because of this other ones could not go forward with enquiries, call meetings, organise people to come and tell us more about this, since the head was aloof and did not want to take part (Frances, 17 September 2001).

In my interview with the Rector it was apparent that the loss of power assumed a far greater level of importance than the educational sacrifices that the incorporation was likely to generate.

GDE has been very negligent ... they just have not sat down as they should have [and] organised some kind of team to deal with it [the incorporation] properly. We have just been sidelined (Rector of the College).

The idea of being sidelined and left out by all the players recurred throughout the interview. Part of the perceived sidelining was that the college simply did not have information about what was going to happen. The Rector repeatedly said that he "did not know" what was happening and what was going to happen to the staff. The sense of not knowing was deeply disempowering. The notion of certainty has been strongly correlated with masculinity and power. Maile (1999, p. 147) argues that "managerial masculinities are ... bound up with loyalties to pre-established working patterns and, if these are threatened,... it is no longer possible for men to feel assured of their status in the organization...". In this framework, managers have to know, to be sure of their decisions and direction and that displaying uncertainty to others in the organisation reduces the power of the leadership. According to Whitehead, (1999, p.107) "if management does not speak with certainty how does it speak?" That the fate of him 
and his staff was in the hands of individuals outside the College was an emasculating reality that probably set the Rector on an adversarial path.

The Rector also suggested the other players had been callous and uncaring. “There is no sympathy [from The University]”; “They certainly didn't have any feelings for us, the GDE"; They [the Council] didn't care anymore"; "We never saw him [the national Minister of Education] despite all the efforts we had put in".

He was also repeatedly deprecating of the university and its leadership.

It [the university] is deteriorating, it has a terrible political history ... It is deteriorating rapidly; it has actually given up being a distance education institution. It's a correspondence institution ... . I think the structure; the management ... has lost direction totally.

The university has lacked direction. It hasn't got a nice core of leaders. ... Leadership implies looking into the future, and it is just not there.

While there was a strong view from respondents of the college and of the other institutions that College staff were nefariously treated in this process, the Rector's comments about the role of the other players were largely, though not solely, in relation to himself as the leader of the College. In a context in which he was structurally disempowered, the Rector sought to assert his authority by threatening a number of the players with legal action. In having lost his authority as the leader, he 
tried to use an entrenched, not easily contested authority - the law. ${ }^{15}$ Towards the end of 2000 the Rector made a submission to the Minister of Education saying that meetings to plan the incorporation were not procedural and that he had taken legal advice on the matter. ${ }^{16}$ He objected to meetings being conducted to facilitate the incorporation process during 2000. His argument was that the period between June 2000 and September 2000 had been set aside for responses to the Minister's promulgation to incorporate the college into the university. In response, the Minister said that the planning meetings were part of the process of determining the feasibility of the incorporation. ${ }^{17}$ However, the Rector was adamant and said that the Minister had "made a decision regarding the College's future, which would appear to have been communicated to the GDE, the University and JET [the external facilitator], and you [the Minister] are, quite frankly, paying lip service to the consultative process". ${ }^{18}$ Interestingly, yet again the core of his complaint revolves around being left out, of his authority being ignored. Arguably, the Rector's anger resonates with notions of the boy's club, of inclusion and exclusion and of being on the outside looking in.

Nothing came of this threat to legal action or, for that matter, from any of the other legal threats that followed.

Two voices of masculinity emerged from the University, the first probably more audible than the other. The first was from a Deputy Dean of the Education Faculty, who had been allocated the responsibility of overseeing the incorporation process vis-

\footnotetext{
${ }^{15}$ Undoubtedly, feminist legal professionals like MacKinnon may argue that this is simply another arena of masculine power.

${ }^{16}$ Submission from the Rector and other signatories to the Minister of Education. 16 November 2000.

${ }^{17}$ Letter from the Minister. 28 November 2000.

${ }^{18}$ Submission from the Rector and other signatories to the Minister of Education. Date uncertain.
} 
à-vis, the Faculty. If the masculinity of the image presented by the college was to be found in the Rector's articulation of his loss of control and his struggle to reaffirm control through legal action, then the masculinity presented by the University took the form of a strong assertion of control by the Deputy Dean. He made it clear that he was in control of the process, and that was the way it should have been. Throughout the interview he made explicit reference to his control of the incorporation process and even went so far as to describe a planning meeting as "my meeting".

I took on what [the external facilitator] was supposed to do. ... I sit on finance committees. I sit on all these infrastructures. I have to get the decisions, monitor them to see that they are implemented, you know all these kinds of stories - even on academic things. I mean I have an overall view and knowledge of what is going on (23 January 2002).

Early in the interview he made it clear that the external facilitator appointed by the DoE had played no role in the process. ${ }^{19}$ When I asked him to evaluate the process he said that the lesson he learnt was that incorporations did not require an external facilitator.

I say this again. ... if I am incorporating something, why must I bring a facilitator? I would say let the receiving institution take charge of the whole process.

He went on to say that, in an incorporation, the receiving institution basically had the authority to decide. When the facilitating agency sent another individual to assist with this incorporation the Deputy Dean found him to be of little value.

\footnotetext{
19 There was widespread agreement among all the role-players that the external facilitator had made no significant contribution to the incorporation process.
} 
I had contact with him [the new facilitator] ... He tried to help here and there, but by that time I was already in control. So there wasn't much for [him] to do.

The assertion that he was in control despite the presence of other senior individuals in the field took other forms as well. In commenting about the role of a senior member of another college that was being simultaneously incorporated into the University and which was also being overseen by the Deputy Dean, he said:

Is it Dr something in Natal? I'll get his name. ... at some stage we did have a heated argument myself and him, outside the meeting hall, because I don't want you anymore in my meetings. You are not helping us with anything (Deputy Dean, 21 January 2002).

Not only did he describe the meeting as his meeting, he implicitly indicated that the role of the others was to help The University. His individual authority and that of the university was unmistakable. His simultaneous derision of the other person by the failure to remember his name was further evocation of his personal and institutional power.

The Deputy Dean also made it clear that even within the University, his control of the process was obvious. When I asked him who was running the College ${ }^{20}$ his answer was

I am. ... He [the Campus Director] is assisting me in running it. But I mean I may not be physically there, but the decisions are made in this office.

\footnotetext{
${ }^{20}$ By this time the Rector of the College had retired. The university had posted a Campus Director, a senior colleague of the Deputy Dean, to manage the College. The Campus Director had been allocated an office at the College.
} 
In commenting on the role of the college in the incorporation process the Deputy Dean's view was that "they created an empire there ... and they feel they are just losing power now".

In a situation of extreme vulnerability for the college, the attitude of the Deputy Dean may have been perceived by some as brutal and aggressive. A number of respondents, including individuals from the GDE, indicated that the university's failure to offer vacancies to the College staff before opening them to the public on the grounds that the university was not party to the bargaining council, where such an agreement was made with respect to all college/university incorporations that were taking place, was a blatant assertion of the University's power in the process. ${ }^{21}$ Such power was reinforced by the university's failure to inform the staff formally that they were not going to make a closed vacancy list available to them. This course of events did not only tell a tale of the power of the university to the staff of the College, but also signalled a level of callousness.

A second, more muted discourse of masculinity that emerged in this incorporation was related to taking over academic control of the college. In my interview with the Campus Director, he said:

We are in fact losing the competition. We are in fact swallowing the competition. If it is based on business principles, we are now responsible for teacher training at a distance in this country (1 August 2001).

\footnotetext{
${ }^{21}$ An agreement signed between the educator unions, provincial education departments and the DoE indicated that staff at closing-down Colleges should be offered a closed vacancy list from the receiving institution, before such vacancies were open to the public. The universities were not party to this bargaining council. Despite this, other universities had followed this procedure. The university was probably the only university that simply ignored this guideline.
} 
This was indeed the case. As a consequence of the incorporation The University became the largest provider for teacher training through distance education in the country. The Campus Director also indicated that student enrolment in the Education Faculty had declined rapidly in the years preceding the incorporation and the incorporation was in some ways a saviour for the Faculty.

The academic authority could also be read in the behavior of some of the staff at the University. One of the tasks of the Academic Programmes Sub-committee, which consisted of representatives of the University, the College and an external curriculum consultant, was to facilitate the academic move of college students to the University. To this end the Sub-committee planned a National Professional Diploma in Education (NPDE). In developing the diploma, the external consultant observed that the academic staff at the university were extremely reluctant to become involved in the process.

It was absolutely impossible to get The University staff except in a supervisory capacity, to take an interest in the college material (Curriculum consultant, 12 February 2002).

While her reading of the reasons for this reluctance was that the University academics did not think that college material was good, a member of the faculty management said that he believed that the University academics were afraid to put their material forward for inclusion into the programme because they were concerned that their material might be shown up to be not very good in comparison with the college material. In other words, they wanted to preserve the sanctity of academic authority that accompanied the status of being university lecturers. The view of the 
management member was in some ways born out by the perceptions of an official at the DoE.

It was really really important to preserve the expertise that existed in distance education ... on the whole the College's product was much better than the University's (DoE official, 30 January 2002).

The disdain towards the college material was also noted by other academics at the University. One lecturer told me that there was a casual announcement in the staff room one day that the college material was available should anyone be interested. He said that no one showed any interest and much of the material was simply ignored. The curriculum consultant summed up the position as follows:

My own goal was to try to preserve the quality that existed at the College and to incorporate that. But I failed.

My contention is that the deliberate disregard shown toward the college material was part of an assertion of authority that simultaneously sought to mask possible weaknesses. The Campus Director made the following general comment about the behavior of senior staff.

... heads of departments sometimes feel very insecure, and threatened and marginalized. They just want to feel that they are in control ... .

I suggest that the negative attitude toward the college material was a means of establishing control in a context of feeling threatened. 
In the main, the impression of the GDE among the College staff was that the GDE simply "did not care" (Kathy, 23 October 2001). This impression was read from the silences of the GDE. According to the College staff, the GDE did not keep them informed of what was going on, they delayed the process and, with the exception of one meeting, had failed to meet with their employees, the staff of the College. Indeed, the curriculum consultant employed by the DoE observed that a senior official in the GDE had repeatedly said that the GDE had a plan but that it was not going to tell anyone what that plan was (12 February 2002). In effect the GDE's silence was perceived to be a form of control and an assertion of power. Some read this silence to mean that the GDE was deliberately silent so that the College staff would resign of their own accord. That the fate of more than 350 individuals lay in the hands of the GDE was a significant reminder of the power of the institution. That they appeared to do nothing was even scarier. Staff expressed a combination of fear and abandonment.

I felt threatened by the GDE - if you do not cooperate we will afdank [fire] you. You can just resign and lose all your benefits. ... I spoke to someone in the GDE and he said okay we haven't placed you anywhere. You don't want to be in Braamfontein. We offer you a package. You can refuse it because it is a mutually agreed package. But then I can use you where I want you. Gauteng goes right up to Vereeniging. ... And obviously that is not a nice idea. Vereeniging. ${ }^{22}$ He threatened me (Jack, 31 October 2001).

Ek persoonlik dink dat die redes vir hierdie inkorporasie is omdat GDE wil ontslae raak van hulle verantwoordlikheid [I personally

\footnotetext{
22 The respondent lives in the province of Gauteng. Braamfontein and Vereeniging are far from his home town but theoretically the GDE could post him there as these areas are still part of Gauteng.
} 
think that the reason for this incorporation is that the GDE wants to give up its responsibilities] (Mabel, 2 August, 2001).

After so many years of service you are just chucked. You are driftwood (Lorraine,26 October 2001).

The combination of fear and an intense awareness of the institutional power commanded by the GDE over the lives of people contributed to the discourse of masculinity that pervaded this incorporation. For some it may have been a dejavu moment - the patriarchal education authorities of the apartheid era instilled much fear in the hearts of educators and the fear of being deployed to some far-off place for failure to tow the line was a reality for many.

Discourses of masculinity, discourses of territoriality

The issue of territoriality prevailed throughout the incorporation process. It began with what would appear to be minor incidents of control over physical space. The Rector of the College refused to allow the University onto the college campus to install computer cabling. He argued that since the incorporation had not been legally finalised, the presence of the University workers on the college was illegal. A further territorial dispute arose when the Deputy Dean of the University was allocated a college car to be used in incorporation-related work. The Rector said this was illegal, as the cars did not officially belong to the University. In both instances the Rector threatened legal action but did not act on his threat.

The staff of the College were equally eager to assert their territorial rights. At one point there was an indication that the offices of some the College staff were to be 
taken over by a neighbouring university. The Registrar responded forcefully and said that he would simply refuse to move the staff. On another occasion there was a rumour that the GDE was going to take over the College offices for use as a district office. What was most disturbing was the presence of workman measuring offices and writing in notebooks. The staff responded by saying that they would barricade themselves in their offices, but they were not going to move.

The occupation of physical space as a means to mark authority was consciously exercised by the University.

... symbolically people wanted me to move in. ... [The Deputy Dean] also told me l've got to move into this office to establish a presence here that The University is now in charge (The university Campus Director at The College, 1 August 2001).

In speaking of the appointment of his assistant the Campus Director said:

And I want an office for her. I said to, “... even if you are here once a week I think it is important for you to have a presence here. And I don't want any office for you. I want this office next door" (1 August, 2001).

The importance of taking the office next door was that it was the office of a senior member of the College management, an individual whom the Campus Director perceived to be uncooperative and destructive in the incorporation process. 
One of the most ridiculous moments in this territorial battle took place when the college held its Durban ${ }^{23}$ graduation ceremony. According to the Campus Director, he and the Deputy Dean agreed that they should attend the ceremony as it was important for their presence to be felt in a province where they had a large student population.

[The Deputy Dean] said to me - you are not travelling with them. We will fly down. Let's stay at the same hotel. And the moment I entered the group, well the whole group dynamic changed completely ... suddenly that group was a little bee group.

The Deputy Dean had sought two ways of asserting the University's authority in this situation. They were not going to drive to the ceremony as the College staff had done but were going to fly there, and they were going to stay at the same hotel thereby making their physical presence visible. What happened was when the Campus Director walked toward a group of the College staff they closed ranks and snubbed him. The territorial game had assumed bizarre levels. Yet it was played repeatedly. Although Moolman's (2004) point is made in relation to territoriality, masculinity and gang warfare, the argument remains relevant. "The competition for acquisition and ownership of land and bodies developed between different groups of men, and remains the case globally....The more capital (land and bodies) acquired (conquered) the more powerful the acquirer, namely man and/collective of men. Gang fights over control of territory (land) often referred to as 'turf wars' (Salo, 2003) are often also messages of dominance and control being communicated to the community and the dominant hegemonic masculinity" (Moolman, 2004, p.113). In

\footnotetext{
${ }^{23}$ A city about $600 \mathrm{kms}$ away from the city of Pretoria where the College and the university are located.
} 
reflecting on his own behaviour John Clark (1999, p.172) confesses, "I noticed my anger and rush to engage in a "turf war", responses that I recognized as being a familiar part of my masculine repertoire".

\section{Some concluding thoughts}

According to Diane Reay and Stephen Ball (2000), there is a significant history of the conflation of leadership and management with masculinity. In this paper I have made distinctive links between the behavior of managers and conceptions of masculinity. Kerfoot and Knights (1999, p.203) make the point that

masculinity often concerns some reference to physical presence, competitive strength ... In management circles, ... masculinity manifests itself less crudely, but nonetheless equally vividly and virulently.

I am not convinced about masculinity being less crudely manifested within management. The territorial battles between the college and the university were stark, at times vicious, and left staff at the lower levels feeling extremely uncomfortable. At one point there was a voluble and somewhat public row between management from the College and that of The University in the staff cafeteria at the College. In effect the territorial battles in this case bear a strong resemblance to the turf wars between rival gangs that Elaine Salo (to be published) so eloquently describes in her article on gangs in the Western Cape. ${ }^{24}$ While the masculinities of gangs in the Western Cape may be expressed through physical violence, the masculinities of academic managers choose the weapons that they know best - words, the control of meetings, the brandishing of status and the control of physical space. Jeff Hearn (1999, p.130)

\footnotetext{
${ }^{24}$ An area in south Africa notorious for the presence of gangs.
} 
observes that historically "... universities had considerable autonomy" and that there was significant coalescence around the notion of territorial autonomy with academic institutions. In this case the territorial autonomy of the college was barely, if at all, recognized by the other players.

In Morrell's (2001) book the issue of territoriality and masculinity is taken up in telling ways. What emerges strongly from the collection is that masculinities are contextually defined and that the masculine subject is likely to have more than one masculinity that defines his or her behavior. Glen Thompson's (2001) article in the collection, in which he describes the parallel masculinities of young black male surfers, is a good example. However, when masculinities defined by similar contexts and contests (universities, colleges and government departments) collide, the battles and consequences become particularly unpleasant. A significant point which emerges here, but which I do not find in the literature on masculinities, is that the intense loudness of the masculine voices that permeated the process had a far more deleterious effect than is at first visible - they eclipse the attempts of others to facilitate the process and to be conscious of the human consequences of their actions. Masculinities mute the efforts to recognise and reward a level of social consciousness that such an intense change process calls for. That the masculinities that prevailed overshadowed the process could be heard in the plaintive voices of respondents who spoke repeatedly of those in power having no sense of humanity that they did not care about what happened to the people in this process.

In the first instance the battles I described here assume a public profile since the players happen to be large public institutions. Hitherto "respected" names in a 
community quickly become controversial characters. Many of the respondents from both the college and the university spoke with a sense of deep hurt and disappointment about the conflict between management structures. Associated with this was a feeling that such battles indicated a lack of concern and sympathy for the plight of the affected staff. One staff member made the point that she no longer knew who was fighting with whom and that so many groups in management constantly fought each other.

Secondly, the reputation of government departments, given the historical legacy of apartheid in South Africa, has been defined by inefficiency and being somewhat inhuman, sinks even lower. Ironically, I spoke to a number of junior government officials who had worked hard to ensure that the staff of the College were assisted in a humane and efficient manner. Yet the abiding impression among the staff at both the college and the university was that the GDE had adopted an attitude of antagonism imbued with a lack of sympathy towards the College. Staff at the College spoke of feeling as though they had "no value" (Lucy, 13 August 2001), of being "dispensable" (20 August 2001) and that their government did not care about them (20 August 2001). Even the Deputy Director-General in the GDE conceded that a moral injustice had been done to the people in the College (Swartz, 19 December 2001). The perception of a "lack of feeling" from the GDE, the DoE and the university is arguably a perception of masculinity. Maile (1999, p.145) suggests that masculinized work cultures are often characterized by a "denial of feelings". Kerfoot (1999, p.196) makes a similar point when she says that masculinity is about sustaining "distance" between masculine managers and others. In other words, it is 
feasible that what the staff of the College experienced was an expression of a masculinized work culture.

Much of the literature on masculinities focuses on theorising and understanding masculinities. It also looks at the ways in which masculinities play themselves out in different contexts. What needs recognition at this point is that masculinities survive and gain predominance, at the expense of other potentially beneficial social practices. That masculinities within management might generate a negative work environment is an incomplete understanding of masculinities; that they do so by silencing and muting other management practices is significant. The fact that there were many behind-the-scenes individuals who were responsible for the staff of the College finally being allocated to suitable posts where possible, that there were people in the management of the College who listened to the fears of the staff, that there were lecturers at the University who wanted to work with lecturers from the College, that there were people who "did the dirty work", that there were many who lost their jobs and their status silently, bears testimony to my contention that masculinities are the loud voices that do not necessarily signal action. Instead, they signal the power games at play. And they silence and obscure the voices and efforts that do act positively. In other words the silences that masculinities engender are potentially destructive to a change environment. Perhaps Macbeth (Shakespeare, Macbeth, Act 5 Scene 5, p.942) knew much more than we assumed when he described his life as a "tale told by an idiot, full of sound and fury, signifying nothing."

Finally, in a context where no individual or corporate fortunes are to be made through the merger, the stakes become even more robustly contested. What is at 
stake is how power gets reallocated within the process and as a consequence of the process. Although it was clear that the Rector of the College was likely to lose power as a consequence of the process, this did not stop him from asserting power in the course of the incorporation process. Although the Deputy Dean was aware that in the end the college would eventually become part of the university, he explicitly and consistently signalled his control of the process. The power of the Deputy Dean was founded in the fact that he was a senior person in an organisation that was acquiring another. The implicit power relations embedded in this outcome reinforced his personal and institutional power. Even more significant though is the apparent reasonableness that pervades such an appropriation of the right to power. Indeed, Michael Kimmel (2000, p.241) takes the position that masculinity is not the experience of power, but the "experience of the entitlement to power". In quoting Seidler's study of masculinity, Kerfooot and Knights (1993, p.671) assert that contemporary masculinity can be seen as "a way of relating to the world wherein everything becomes an object of and for control ... this form of control ... equates with reason, logic and rational process; [it] generates and sustains a hierarchy imbued with instrumentalism, careerism and the language of 'success'... ." They go on to say (1993, p. 672) "in organizational sites ... competitive masculinity serves to rank individuals in terms of their capacity to display attributes of control...." What the behaviors of specific managers suggest is that masculinity, expressed through the desire for control, echoed throughout this incorporation process.

In this education merger the masculinities at play had a visible impact on the public perceptions of the process and on the outcomes for the institutions involved. The question that resounds in the aftermath of this incorporation is whether the 
marriage metaphors that pervade the literature on mergers and acquisitions are not unwittingly and inadvertently more appropriate than intended - that marriages are often about power and control, about territoriality and, in the historical unfolding of the nature of marriages, about the assertion of masculinity? 


\section{Bibliography}

Brittan, A. (1989) Masculinity and power (New York, Basil Blackwell).

Brooks, A (2001) Restructuring bodies of knowledge, in: A. Brooks \& A. Mackinnon (Eds), Gender and the restructured university (UK, The Society for Research into Higher Education \& Open University Press).

Clark, J (1999) A personal encounter: exploring the masculinity of management through action research, in: S. Whitehead \& R. Moodley (Eds) Transforming managers: gendering change in the public sector (London, UCL Press), 166-183.

Connell, R.W. (1995) Masculinities (Cambridge, Polity Press).

Connell, R.W. (2000) The men and the boys (Cambridge, Polity Press).

Connell, R.W. (2002) Gender (Malden, Massachusetts, Blackwell Publishers).

Davies, L. (1998) Democratic practice, gender and school management, in: P. Drake \& P. Owen (Eds) Gender and management issues in education (Stroke on Trent, Staffordshire, Trentham Books Limited), 13-32.

Hearn, J. (1999) Men, managers and management: the case of higher education, in: S. Whitehead \& R. Moodley (Eds) Transforming managers: gendering change in the public sector (London, UCL Press),123-144. 
Hearn, J. (2001) Academia, management and men: making the connections, exploring the implications, in: A. Brooks \& A. Mackinnon (Eds) Gender and the restructured university (UK, The Society for Research into Higher Education \& Open University Press).

Hofmeyr, J. \& Hall, G. (1996) The national teacher education audit - synthesis report (Pretoria, National Department of Education).

Holter , Ø. G. (1989) Menn (Oslo, Aschehoug).

Kerfoot, D. (1999) The organization of intimacy: managerialism, masculinity and the masculine self in: S. Whitehead \& R. Moodley (Eds) Transforming managers: gendering change in the public sector (London, UCL Press), 184-199.

Kerfoot, D \& Knights, D. (1993) Management, masculinity and manipulation: from paternalism to corporate strategy in financial services in Britain, Journal of Management Studies, 30, 659-677.

Kerfoot, D and Knights, D. (1999) "Man" management: ironies of modern management in an "old" university, in: S. Whitehead \& R. Moodley (Eds) Transforming managers: gendering change in the public sector (London, UCL Press), 200-213. 
Kerfoot, D and Whitehead, S. (2002) Keeping all the balls in the air: further education and the masculine/managerial subject, Journal of Further and Higher Education, 24 (2), 192-

Kimmel, M (2000) Reducing men's violence: the personal meets the political, in: I. Breines, R. Connell \& E. Eide (Eds) Male roles, masculinities and violence: a culture of peace perspective. (Paris, UNESCO Publishing), 239-248.

MacKinnon, C. (1983) Feminism, Marxism, method and the state: toward feminist jurisprudence, Signs, 8, 636-658.

Maile, S. (1999) Intermanagerial rivalries, organizational restructuring and the transformation of management masculinities, in: S. Whitehead \& R. Moodley (Eds) Transforming managers: gendering change in the public sector (London, UCL Press), $145-165$.

Moolman, B. (2004) The reproduction of an 'ideal' masculinity through gang rape on the Cape Flats, Agenda, 60, 109-123.

Morrell, R. (2000) South African men in the post-apartheid era: responses, dangers and opportunities, in: I. Breines, R. Connell \& E. Eide (Eds) Male roles, masculinities and violence (Paris, UNESCO Publishing), 107-116. 
Morrell, R. (2001) The times of change: Men and masculinity in South Africa, in: R. Morrell (Ed) Changing men in Southern Africa (Pietermaritzburg, University of Natal Press), 3-37.

Morrison, A. (1987) Breaking the glass ceiling. (Reading, Addison Wesley).

National Commission on Higher Education (NCHE). (1996) A framework for transformation (Cape Town, NCHE).

Nicholson, P. (1996) Gender, power and organization (London, Routledge).

Prichard, C. (1996) Managing universities: is it men's work?, in: D.L. Collinson \& J. Hearn (Eds.), Men as managers, managers as men: critical perspectives on men, masculinities and managements (London, Sage).

Reay, D. \& Ball, S. (2000) Essentials of female management: women's ways of working in the education marketplace? Educational Management and Administration, 28(2), 145-159.

Salo, E. (2003) Negotiating gender and personhood in the new South Africa: adolescent women and gangsters of Manenberg Township on the Cape Flats, Forthcoming in European Journal of Cultural Studies.

Schmitt, R. (2001) Some final thoughts, Men and masculinities, 3, 411-413. 
Schwalbe, M. (1996) Unlocking the iron cage: the men's movement, gender politics and American Culture (New York, Oxford University Press).

Shakespeare, W. Macbeth, in: In B. Hodek (1976) $17^{\text {th }}$ impression The complete works of William Shakespeare (London, Hamlyn Publishing Group).

Soobrayan, V. (2002) Transformation or travesty? A study of the micropolitics of educational change in the case of the incorporation of a college of education into a university. Unpublished doctoral thesis, University of Pretoria.

Thompson, G. (2001) Making waves, making men: the emergence of a professional surfing masculinity in South Africa during the late 1970s, in: R. Morrell (Ed) Changing men in Southern Africa (Pietermaritzburg, University of Natal Press), 91-104.

Whitehead, S. (1999) Contingent masculinities: disruptions to "man"ageralist identity, in: S. Roseneil \& J. Seymour (Eds) Practising identities: power and resistance (USA, St. Martins Press Inc). 